K A N D A I

\begin{tabular}{|l|l|l|}
\hline Volume 15 & No. 1, Mei 2019 & Halaman 1-12 \\
\hline
\end{tabular}

\title{
SIKAP BAHASA REMAJA URBAN TERHADAP BAHASA INDONESIA DI ERA MILENIAL \\ (The Language Attitude of Urban Teenagers Towards Indonesian in The Millennial Era)
}

\author{
Nuryani \\ Fakultas Ilmu Tarbiyah dan Keguruan \\ Universitas Islam Negeri Syarif Hidayatullah Jakarta \\ Jalan Ir. H. Djuanda, Nomor 95 Ciputat, Tangerang Selatan, Indonesia \\ nuryani@uinjkt.ac.id
}

(Diterima 25 Januari 2019; Direvisi 8 Mei 2019; Disetujui 9 Mei 2019)

\begin{abstract}
The problem in this paper is how do teenagers behave in Indonesian language in the millennial era? The aim is to describe the adolescent language attitude towards Indonesian in the millennial era. The subjects in this study were adolescents who's age ranged between 15 to 20 years old. Language attitude questionnaire with three characteristics of language attitude by Gavin and Mathiot as references, is using as data retrieval method. The results of the study show that teenagers living in urban areas have a negative language attitudes tendency towards Indonesian. This can be seen from their very lack of pride in Indonesian. Likewise, the indicators of loyalty and awareness of rules of norms in the Indonesian language show a negative attitude. In addition, negative language attitudes can also be seen from the diction they use when speaking or uploading status on social media.

Keywords: language attitudes, urban teenagers, millenial era

\section{Abstrak}

Permasalahan dalam tulisan ini adalah bagaimana sikap remaja terhadap bahasa Indonesia di era milenial? Tujuannya adalah untuk mendeskripsikan sikap bahasa remaja terhadap bahasa Indonesia di era milenial. Subjek dalam penelitian ini adalah remaja yang rentang usianya antara 15 sampai 20 tahun. Metode pengambilan data menggunakan angket sikap bahasa dengan menggunakan tiga ciri sikap bahasa menurut Gavin dan Mathiot sebagai acuan. Hasil penelitian menunjukkan bahwa para remaja yang tinggal di wilayah urban memiliki kecenderungan sikap bahasa yang negatif terhadap bahasa Indonesia. Hal tersebut terlihat dari rasa bangga mereka yang sangat kurang terhadap bahasa Indonesia. Demikian juga dengan indikator pada kesetiaan dan kesadaran akan norma kaidah dalam bahasa Indonesia menunjukkan sikap yang cenderung negatif. Selain itu, sikap bahasa yang negatif juga terlihat dari diksi yang mereka gunakan ketika berbicara maupun ketika mengunggah status di media sosial.

Kata-kata kunci: sikap bahasa, remaja urban, era milenial
\end{abstract}




\section{PENDAHULUAN}

Bahasa memiliki kedudukan yang sangat penting dalam kehidupan manusia. Manusia menggunakan bahasa dalam setiap segi kehidupannya. Kemunculan bahasa bersamaan dengan munculnya sejarah sosial komunitaskomunitas yang dalam pengertian modern disebut masyarakat atau bangsa (Chaer \& Agustina, 1995, hlm. 19). Melalui bahasa itulah manusia dapat menyampaikan segala yang dipikirkan, yang diharapkan, dan untuk berinteraksi sebagai makhluk sosial. Apabila manusia tidak memiliki bahasa maka manusia akan kehilangan kesanggupan hidup sebagai makhluk sosial (Nababan, 1993, hlm. 46). Dengan demikian, dapat dikatakan bahwa bahasa memegang peranan penting dan tidak dapat dipisahkan dalam setiap kegiatan manusia.

Memasuki era milenial bahasa menjadi lebih berarti karena dapat disampaikan dengan cepat ke berbagai daerah. Selain itu, bahasa menjadi cara bagi manusia untuk diakui keberadaannya. Melalui berbagai sarana, perkembangan bahasa dirasakan sangat cepat. Demikian juga dengan penggunaan bahasa yang semakin berkembang seiring dengan berkembangnya teknologi di era milenial.

Perkembangan tersebut tidak hanya dirasakan pada sisi persebaran tetapi juga pada pilihan bahasa yang digunakan. Pilihan bahasa ini menjadi salah satu indikator dari sikap bahasa yang dimiliki oleh pengguna bahasa. Kecenderungan penggunaan bahasa di era milenial ini sangat beragam, salah satunya banyak ditemukan penggunaan bahasa asing. Penggunaan bahasa asing pada hampir semua bidang kehidupan memang tidak terelakkan. Penyebabnya antara lain adalah hal atau sesuatu yang baru yang berasal dari luar, belum adanya padanan kata terhadap hal atau benda tersebut di dalam bahasa Indonesia, dan sikap masyarakat pengguna bahasa yang pro bahasa asing ketimbang bahasa lokal (Zalmansyah, A., Zakiah, N. \& Isnaini, 2018, hlm. 150). Hal itu pula yang terjadi pada remaja di era milenial dalam menggunakan dan memilih bahasa. Keberadaan mereka cukup memengaruhi persebaran bahasa melalui media sosial.

Masa remaja merupakan masa transisi dari anak-anak menjadi lebih dewasa. Masa ini ditandai dengan munculnya atau berubahnya pola pikir dan perilaku. Demikian juga dengan perilaku berbahasa yang cenderung terlihat perubahannya. Remaja tidak ingin dianggap sebagai anak kecil sehingga sebisa mungkin memperlihatkan perubahannya melalui bahasa yang mereka gunakan. Sebagai anak yang ingin diakui keberadaannya dan dianggap memiliki pendidikan lebih tinggi mereka cenderung menggunakan bahasa yang oleh sebagian orang dianggap "menyalahi" aturan. Melihat hal yang demikian, menarik untuk melihat pilihan bahasa yang mereka gunakan dalam berbagai ranah.

Remaja yang tumbuh di lingkungan kota, desa, dan wilayah urban tentu saja memiliki berbagai perbedaan. Perbedaan dari sisi bahasa juga dapat dilihat dari berbagai pilihan kata yang mereka gunakan dalam keseharian. Wilayah urban yang merupakan wilayah transisi antara kota dan desa menjadi tempat tersebarnya berbagai informasi menarik. Demikian juga dengan remaja yang tumbuh dan berkembang di wilayah urban memiliki kecenderungan yang menarik untuk dilihat sisi bahasanya.

Pertumbuhan bahasa yang digunakan remaja di wilayah urban ini sangat beragam. Keberagaman tersebut 
muncul dengan beragam alasan. Berbagai alasan yang muncul menjadi bahasan yang melatarbelakangi pandangan remaja terhadap bahasa Indonesia. Oleh karena itu, penelitian ini bertujuan melihat dan mendeskripsikan sikap bahasa remaja terhadap bahasa Indonesia di era milenial.

Masalah yang menjadi fokus dalam penelitian ini adalah bagaimana sikap bahasa remaja terhadap bahasa Indonesia di era milenial? Permasalahan dikaji pada pada remaja di wilayah urban. Adapun tujuan penelitian ini adalah untuk mendeskripsikan sikap bahasa remaja terhadap bahasa Indonesia di era milenial, terutama mereka yang tinggal di wilayah urban).

\section{LANDASAN TEORI}

Teori yang digunakan sebagai dasar dan pijakan menganalisis data dalam penelitian ini antara lain teori sikap bahasa, faktor yang memengaruhi sikap bahasa remaja, dan wilayah urban.

\section{Sikap Bahasa}

Sikap bahasa dapat diartikan
sebagai sebuah perilaku atau kesopananan bereaksi terhadap suatu keadaan kebahasaan. Sikap bahasa ini dapat diamati antara lain melalui perilaku berbahasa atau perilaku bertutur (Aslinda \& Syafyahya, 2010, hlm. 10). Melalui cara berbahasa, bertutur, dan memilih kata atau bahasa tertentu bisa memperlihatkan pandangan atau sikap seseorang terhadap suatu bahasa. Sikap bahasa ini pula yang akan membentuk persepsi dan perlakuan seseorang terhadap bahasa.

Sikap dapat cenderung positif maupun negatif. Kecenderungan sikap ini akan terlihat dari beberapa poin yang menjadi indikator. Sikap positif nantinya akan membetuk perilaku dan pandangan yang positif juga terhadap bahasa. Demikian pula dengan sikap negatif yang nantinya akan membentuk perilaku dan pandangan yang negatif pula terhadap bahasa. Kecenderungan sikap ini akan membuat pengguna bahasa memilih diksi dalam kegiatan berbahasa. Diksi atau pilihan kata yang digunakan juga dilihat, karena hal tersebut juga menjadi salah satu indikator akan sikap bahasa yang dimiliki. Peneliti melihat diksi yang digunakan selama berbincang dan melalui unggahan di akun media sosial mereka.

Penelitian ini menggunakan tiga ciri sikap bahasa yang dikemukakan oleh Gavin dan Mathiot sebagai indikator untuk menilai sikap bahasa (Jendra, 2010). Ketiga ciri tersebut adalah sebagai berikut.

\section{Kesetiaan Bahasa}

Kesetiaan bahasa adalah sikap setia terhadap bahasa dengan memperlakukan bahasa tersebut sebagai yang utama. Sikap setia terhadap bahasa mendorong pengguna bahasa mempertahankan bahasanya. Dengan sikap ini pula pengguna bahasa atau komunitas bahasa berusaha untuk mencegah adanya pengaruh dari bahasa lain.

\section{Kebanggaan Bahasa}

Kebanggaan terhadap bahasa dapat diartikan sebagai tindakan atau perilaku yang dapat mendorong orang untuk mengembangkan bahasanya. Komunitas pengguna bahasa beruasaha menggunakan bahasa tersebut sebagai lambang identitas dan kesatuan masyarakat. Dengan kebanggaan mereka terhadap bahasanya mereka akan berusaha menjaga bahasanya sebaik mungkin. 


\section{Kesadaran Akan Adanya Norma Bahasa}

Norma bahasa dapat berupa kaidah atau aturan yang diterapkan atau yang ditentukan dalam sebuah bahasa. Setiap bahasa di suatu wilayah memiliki aturan yang harus dipatuhi. Aturan atau kaidah ini dibuat sebagai sarana standardisasi bahasa. Hal tersebut penting guna membuat suatu bahasa diakui keberadaannya.

Ketiga ciri yang dikemukakan di atas menggambarkan sikap bahasa baik positif maupun negatif. Apabila kecenderungan poin yang dipilih lebih banyak pada pernyataan negatif, menunjukkan sikap yang dimiliki adalah sikap negatif. Demikian juga sebaliknya, ketika kecenderungan poin yang dipilih adalah pernyataan positif maka menunjukkan sikap bahasa yang positif. Sikap bahasa yang positif ditunjukkan dengan adanya rasa bangga dan setia terhadap bahasa yang dimiliki, dalam hal ini adalah bahasa Indonesia. Selain itu, ketaatan dan kesadaran akan norma atau adanya kaidah dalam bahasa Indonesia dapat menunjukkan bahwa penutur memiliki sikap yang positif terhadap bahasa Indonesia. Apabila sikap-sikap yang demikian telah hilang maka menunjukkan adanya sikap yang negatif terhadap bahasa Indonesia.

Sikap negatif terhadap suatu bahasa dapat terjadi juga apabila seseorang atau sekelompok masyarakat penutur tidak lagi memiliki rasa bangga terhadap bahasanya. Mereka cenderung mengalihkan rasa bangganya terhadap bahasa yang lain. Selain itu, banyak faktor yang dapat menyebabkan hilangnya rasa bangga terhadap bahasa sendiri dan beralih ke bahasa yang lain. Faktor tersebut antara lain politik, ras, etnis, ekonomi, gengsi, dan lain sebagainya.

\section{Remaja di Era Milenial}

Perkembangan zaman telah berjalan sangat cepat. Perubahan dari generasi ke generasi tidak dapat terelakkan lagi. Munculnya generasi baru membawa mimpi tersendiri bagi setiap negara. Jargon yang sangat terkenal dari seorang Soekarno adalah "bawakan kepadaku 10 pemuda maka akan aku ubah dunia”. Jargon tersebut bukanlah tanpa dasar. Soekarno seorang yang sangat visioner mampu melihat potensi bahwa dalam diri pemuda menyimpan energi yang luar biasa untuk dapat dimanfaatkan. Sama halnya di era sekarang pemuda sangat memegang peranan penting. Oleh karenanya pemuda harus mempersiapkan diri sebaik mungkin guna menyambut era kepemimpinan mereka. Akan tetapi, akan terjadi sebaliknya jika pemuda hanya berpangku tangan dan acuh terhadap lingkungan mereka.

Generasi milenial cenderung lebih tidak peduli terhadap keadaan sosial di sekitar mereka seperti dunia politik ataupun perkembangan ekonomi Indonesia (Syahrir, 2018). Lalu pertanyaannya adalah siapakah generasi milenial ini? Masih menurut Syahrir, generasi milenial adalah mereka yang lahir di rentang tahun 1980-2000-an. Generasi milenial atau juga dikenal dengan generasi Y memiliki keunggulan tersendiri terutama dalam bidang pendidikan dan teknologi. Keunggulan tersebut merupakan potensi besar yang sebenarnya harus terus digali guna memajukan dan mengembangkan negara Indonesia.

Hal sebaliknya akan terjadi jika potensi tersebut tidak dikembangkan secara optimal. Generasi ini hanya akan menjadi beban negara tanpa ada sumbangsih positif. Oleh karenanya perlu dilakukan upaya guna mengembangkan potensi sehingga 
menumbuhkan rasa tanggung jawab terhadap negara.

Alvara Research Center mencoba melakukan prediksi wajah Indonesia di tahun 2020. Prediksi tersebut didasarkan pada tiga fenomena yang terjadi di Indonesia, yakni pergeseran komposisi urban-rural, penduduk kelas menengah, dan komposisi penduduk muda (Hasanudin \& Purwandi, 2016, hlm. 7). Menurut penelitian ini lebih dari 33\% penduduka Indonesia tahun 2015 adalah penduduk muda yang berusia $15-34$ tahun, bahkan untuk daerah perkotaan seperti DKI Jakarta penduduk mudanya bisa mencapai lebih dari $40 \%$. Masih menurut penelitian ini bahwa mereka inilah yang kemudian dikenal sebagai generasi milenial (Hasanudin \& Purwandi, 2016, hlm. 13).

Generasi milenial merupakan generasi unik dan berbeda dengan generasi lain. Hal tersebut banyak dipengaruhi oleh munculnya ponsel pintar, meluasnya internet, dan munculnya jejaring sosial media. Ketiga hal tersebut banyak memengaruhi pola pikir, nilai-nilai, dan perilaku yang dianut (Hasanudin \& Purwandi, 2016, hlm. 15). Berdasarkan hal tersebut maka dapat dikatakan bahwa generasi milenial adalah mereka yang lahir setalah generasi $\mathrm{X}$ dengan keunikan dalam berbagai bidang khususnya teknologi. Keakraban mereka dengan teknologi membawa dampak pada pola sikap berbahasa mereka. Teknologi dan budaya barat yang cenderung lebih mudah diakses membuat mereka juga lebih mudah mengubah cara berpikir sesuai dengan yang mereka akses. Demikian juga dengan cara mereka bersikap terhadap bahasa yang cenderung akomodatif terhadap hal-hal baru yang "berbau modernitas".

\section{Masyarakat Urban}

Masyarakat urban adalah masyarakat yang melakukan urbanisasi. Urbanisasi adalah perpindahan penduduk dari desa ke kota (Hartono, 2009, hlm. 34). Desa merupakan organisasi atau kumpulan kehidupan sosial dalam suatu daerah yang terbatas. Sementara itu, kota merupakan sistem jaringan kehidupan manusia yang ditandai dengan kepadatan penduduk yang tinggi, strata sosial ekonomi yang heterogen, dan kehiduapan materialistis (Susilawati, 2009, hlm. 68). Rahardjo menggambarkan bahwa pola saling hubungan masyarakat di kota telah mengarah pada rasional, egois, impersonal, dan kurang intim. James A Quin dalam bukunya Urban Society bahwa yang membedakan antara masyarakat kota dan desa dapat dilihat dari tiga hal, yakni peranan masingmasing anggota masyarakat, lapangan pekerjaan, dan komposisi sosial (2007, hlm. 59).

Wilayah urban dapat dikatakan sebagai wilayah yang ditempati atau didiami oleh masyarakat dari hasil urbanisasi. Masyarakat yang berasal dari desa beralih mendiami kota yang kemudian membuat kelompok baru. Kelompok baru ini akan membuat struktur sosial dan pola bahasa yang baru. Wilayah Tangerang Selatan dapat dikatakan sebagai wilayah urban mengingat wilayah ini banyak didiami oleh masyarakat yang berasal dari berbagai desa yang mencari peruntungan ke kota. Wilayah Tangerang Selatan yang berbatasan langsung dengan Jakarta Selatan menjadi lokasi pilihan bagi warga yang bekerja di Jakarta untuk bertempat tinggal.

Urbanisasi sebagai salah satu bentuk migrasi menjadi salah satu faktor yang memengaruhi atau mendorong terjadinya pergeseran bahasa 
(Sumarsono, 2010, hlm. 236). Beberapa hal yang mendorong terjadinya pergeseran bahasa adalah sebagai berikut. Pertama, kelompok-kelompok kecil bermigrasi ke daerah atau negara lain yang tentu saja menyebabkan bahasa mereka tidak berfungsi di daerah baru. Kedua, gelombang besar penutur bahasa bermigrasi membanjiri sebuah wilayah kecil dengan sedikit penduduk, menyebabkan penduduk setempat terpecah dan bahasanya bergeser.

\section{METODE PENELITIAN}

Berikut akan diuraikan metode penelitian yang digunakan dalam penelitian ini, yaitu metode langsung dan tak langsung. Selain itu, tahapan penelitian yang dilakukan juga akan diuraikan satu persatu.

Dalam penelitian sikap bahasa terdapat dua metode yang dapat digunakan, yakni metode langsung dan metode tidak langsung (Jendra, 2010, hlm. 106). Metode langsung adalah metode yang digunakan dalam pengukuran sikap bahasa dengan mengajukan pertanyaan secara langsung dalam sebuah wawancara. Selain itu, dapat juga dilakukan dengan memberikan pertanyaan untuk diisi oleh responden. Dalam metode ini pewawancara mengajukan pertanyaan dan respon manakah yang menyatakan secara langsung sikap bahasa responden. Sementara itu, metode tidak langsung adalah metode pengukuran sikap bahasa di mana responden tidak menyadari bahwa yang bersangkutan sedang diamati sikap bahasanya.

Penelitian ini menggunakan metode langsung. Peneliti membuat daftar angket untuk melihat sikap bahasa subjek penelitian. Angket yang disusun didasarkan pada indikator yang telah dibuat. Indikator ini didasarkan pada tiga ciri sikap bahasa yang dikemukakan oleh Gavin dan Mathiot.

Subjek dalam penelitian ini berjumlah 50 remaja yang memiliki rentang usia antara 15-20 tahun. Remaja yang menjadi subjek penelitian selain memenuhi unsur usia, mereka juga memiliki akun di media sosil dan tinggal di wilayah urban. Sementara itu, objek dalam penelitian ini adalah sikap bahasa yang dimiliki oleh remaja yang tinggal di wilayah urban. Remaja ini hidup di era milenial dan akrab dengan teknologi yang ditandai dengan kepemilikan dan keaktifan di media sosial. Penelitian dilaksanakan pada bulan Agustus 2018 dan berlokasi di wilayah Tangerang Selatan. Wilayah ini dianggap sebagai wilayah urban dengan perkembangan yang cukup pesat.

Penelitian ini menggunakan metode langsung yang diterjemahkan dalam teknik pengumpulan data dalam bentuk angket/kuesioner. Angket berisi daftar pernyataan yang telah disusun oleh peneliti berdasarkan teori yang digunakan sebagai rujukan. Tabel 1 berikut memuat daftar pernyataan yang terdapat dalam angket.

Tabel 1

Daftar Pernyataan Angket

\begin{tabular}{l|l|l|l|l|l}
\hline \multirow{2}{*}{ No } & \multicolumn{1}{|c|}{ Pernyataan } & \multicolumn{3}{c}{ Skala } \\
\cline { 3 - 5 } & SS & S & KS & TS \\
\hline 1 & $\begin{array}{l}\text { Menjaga dan memelihara } \\
\text { bahasa Indonesia sebagai } \\
\text { bahasa nasional. }\end{array}$ & & & & \\
\hline 2 & $\begin{array}{l}\text { Merasa memiliki bahasa } \\
\text { Indonesia sehingga harus } \\
\text { dilestarikan. }\end{array}$ & & & & \\
\hline 3 & $\begin{array}{l}\text { Perlu mempelajari dan } \\
\text { memperdalam bahasa } \\
\text { Indonesia meskipun } \\
\text { bahasa tersebut sudah } \\
\text { dikuasai. }\end{array}$ & & & & \\
\hline \multirow{2}{*}{$\begin{array}{l}\text { Orang tua lebih senang } \\
\text { dan bangga melihat Anda } \\
\text { menguasai bahasa } \\
\text { Indonesia dibandingkan } \\
\text { bahasa asing. }\end{array}$} & & & & & \\
\hline 5 & $\begin{array}{l}\text { Merasa bangga dapat } \\
\text { berbicara bahasa }\end{array}$ & & & & \\
\hline
\end{tabular}




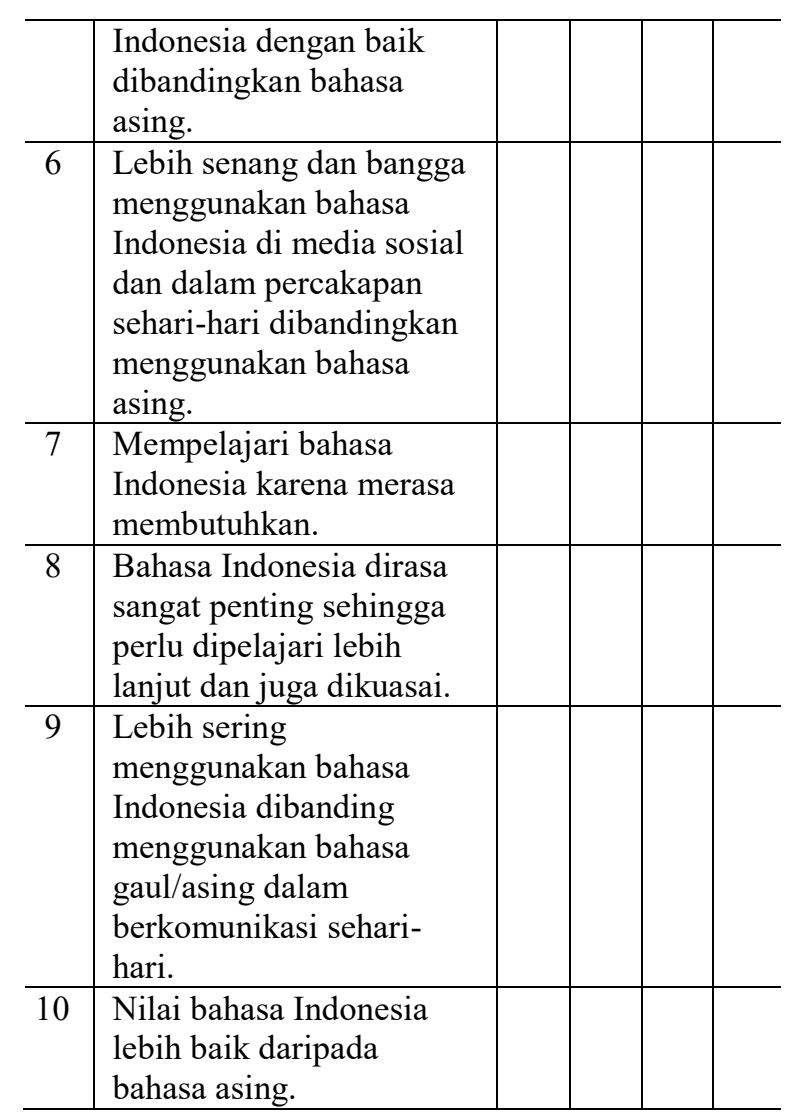

Pernyataan disusun berdasarkan ciri sikap bahasa yang disampaikan oleh Gavin dan Mathiot. Dengan persebaran ciri kesetiaan terdapat pada pernyataan 1, 2, dan 9. Persebaran ciri kebanggaan terdapat pada pernyataan 4, 5, dan 6 . Sementara itu, persebaran ciri kesadaran akan norma berbahasa terdapat pada pernyataan 3, 7, 8, dan 10 .

Penelitian ini juga menggunakan teknik triangulasi data untuk lebih memastikan keabsahan data. Triangulasi data dilakukan dengan melakukan wawancara terbuka dan melihat atau mengamati akun media sosial mereka. Berdasarkan wawancara terbuka akan terlihat pilihan kata yang mengarahkan kecenderungan sikap bahasa yang mereka miliki.

$$
\text { Pertanyaan diajukan guna }
$$
memperkuat analisis terhadap ciri sikap bahasa remaja terhadap bahasa Indonesia. Berikut beberapa daftar pertanyaan yang menjadi acuan.
1. Apakah kalian memiliki akun di media sosial?

2. Apakah saya diperbolehkan melihat akun media sosial kalian?

3. Apa yang sering kalian tuliskan di media sosial?

4. Mengapa kalian menggunakan bahasa yang seperti ini di media sosial?

\section{Teknis Analisis Data}

Teknik analasisis data yang digunakan dalam penelitian ini meliputi deskriptif kualitatif dan verifikatif kualitatif (Mahsun, 2011, hlm. 257). Selain itu, penelitian ini juga menggunakan teknik campuran antara kuantitaif dan kualitatif. Teknik kuantitaif dilakukan karena data yang diambil juga berupa angka-angka sehingga membutuhkan penghitungan untuk analisisnya. Data angka diperoleh dari hasil penyebaran angket, dengan menggunakan rumus persentase sebagai berikut.

$$
\mathrm{P}=\frac{\mathrm{F}}{\mathrm{N}} \times 100 \%
$$

Keterangan:

$\mathrm{F}=$ frekuensi yang sedang dicari persentasenya

$\mathrm{N}=$ Number of Case (jumlah frekuensi atau banyaknya individu)

$\mathrm{P}=$ angka persentase

(Lasmawati, 2012, hlm. 35-36).

\section{PEMBAHASAN}

Wilayah Tangerang Selatan (Tangsel) merupakan wilayah pemekaran yang baru berusia 10 tahun di tahun ini (Pemerintah Kota Tangerang Selatan, tt.). Meskipun usianya relatif muda, tidak membuat wilayah ini tertinggal. Justru di usia yang masih sangat muda wilayah Tangsel telah menjadi wilayah yang maju dan sangat berkembang dari berbagai sisi. Tangsel menjadi wilayah pilihan para 
kaum urban untuk bertempat tinggal. Jarak Tangsel hanya kurang dari $30 \mathrm{~km}$ dari wilayah DKI Jakarta. Bahkan, Tangsel berbatasan langsung dengan DKI Jakarta di sebelah timurnya. Letak geografis Tangerang Selatan yang berbatasan dengan Provinsi DKI Jakarta pada sebelah utara dan timur memberikan peluang pada Kota Tangerang Selatan sebagai salah satu daerah penyangga provinsi DKI Jakarta.

Banyak masyarakat melakukan kegiatan urbanisasi dari berbagai daerah di Indonesia. Pilihan mereka adalah bekerja di wilayah DKI Jakarta dan sekitarnya. Banyak di antara mereka yang pada akhirnya membangun keluarga dan membentuk komunitas di tempat baru. Bekerja di Jakarta adalah sebuah keniscayaan bagi mereka dan melihat nilai jual tempat tinggal di Jakarta yang dirasa tidak mungkin maka daerah di pinggir Jakarta adalah pilihan yang tepat bagi mereka. Salah satu wilayah yang menjadi pilihan adalah Tangerang Selatan. Banyak di antara mereka yang bekerja di Jakarta tetapi memilih tinggal di Tangsel.

Banyak di antara mereka yang sudah tinggal di wilayah ini dari generasi ke generasi. Dari banyak remaja yang ditemui, umumnya mengaku bukan warga asli Tangsel maupun Betawi. Akan tetapi, mereka mengaku lahir dan dibesarkan di wilayah urban ini. Pergaulan mereka juga dipengaruhi oleh wilayah yang mereka tinggali. Demikian juga dengan penggunaan bahasa mereka baik di sekolah, di lingkungan keluarga, maupun pergaulan di lingkungan masyarakat. Oleh karena itu, menarik untuk melihat perkembangan bahasa dan sikap bahasa remaja di wilayah urban di era milenial ini.

Kuesioner berisikan sepuluh (10) pernyataan mengenai sikap bahasa remaja terhadap bahasa Indonesia (dicantumkan dalam subbab teknik pengumpulan data). Untuk melakukan analisis data, peneliti membuat tabulasi data atau pengumpulan data secara keseluruhan.

Tabel 2

Tabulasi Data Kuesioner Sikap Bahasa

\begin{tabular}{c|c|c}
\hline \multirow{2}{*}{ Pernyataan } & \multicolumn{2}{|c}{ Skala } \\
\cline { 2 - 3 } & $\begin{array}{c}\text { Positif (\%) } \\
\text { (SS dan S) }\end{array}$ & $\begin{array}{c}\text { Negatif (\%) } \\
\text { (KS dan TS) }\end{array}$ \\
\hline 1 & 34 & 66 \\
\hline 2 & 20 & 80 \\
\hline 3 & 94 & 6 \\
\hline 4 & 28 & 72 \\
\hline 5 & 20 & 80 \\
\hline 6 & 46 & 54 \\
\hline 7 & 13 & 87 \\
\hline 8 & 48 & 52 \\
\hline 9 & 67 & 33 \\
\hline 10 & 28 & 72 \\
\hline
\end{tabular}

Berdasarkan Tabel 2 di atas, dapat diketahui bahwa persentase paling banyak adalah yang memilih pernyataan tidak setuju. Pernyataan pada kuesioner (terdapat pada subbab teknik pengumpulan data) dalam penelitian ini adalah pernyataan yang menggiring pada sikap positif. Pernyataan positif artinya jika responden memilih poin setuju atau sangat setuju (positif) dalam jumlah yang besar atau lebih banyak dari yang memiliki poin tidak setuju atau kurang setuju (negatif) maka mengindikasikan bahwa sikap bahasanya adalah positif. Hal tersebut berlaku juga sebaliknya. Artinya, jika lebih banyak responden yang memilih poin pada kurang setuju atau tidak setuju maka mengindikasikan sikap bahasa yang negatif.

Melihat penjelasan tersebut, maka jika dilihat dari persentase dalam Tabel 2, diketahui bahwa lebih banyak responden yang memilih pada poin kurang setuju atau tidak setuju. Dengan demikian, merujuk pada isi atau sifat pernyataan dalam kuesioner maka dapat dikatakan bahwa hal tersebut mengindikasikan pada sikap bahasa yang negatif. 
Pembahasan dalam artikel ini akan dilakukan sesuai dengan poin yang terdapat pada angket. Dengan begitu, akan lebih jelas dalam menganalisis persentase sikap bahasa yang positif dan negatif. Selain itu, karena antara pernyataan yang satu dengan yang lain memiliki keterkaitan maka pembahan juga dilakukan dengan melihat keterkaitan tersebut. Adapun hal-hal yang terkait dengan angket akan dijelaskan secara lebih detil berikut ini.

Merujuk pada teori Gavin dan Mathiot, pernyataan pertama ini terkait dengan rasa setia terhadap bahasa Indonesia. Adapun bunyi pernyataan pertama adalah "Menjaga dan memelihara bahasa Indonesia sebagai bahasa nasional". Dengan pernyataan tersebut peneliti ingin melihat rasa setia remaja terhadap bahasa Indonesia. Dengan kesetiaan yang mereka miliki maka mereka berusaha untuk ikut menjaga dan memelihara keberlangsungan bahasa tersebut. Berdasarkan angket yang diisi oleh responden sebanyak 17 responden atau $34 \%$ responden memilih jawaban yang mengindikasikan positif. Sementara itu, responden yang memilih poin negatif sebanyak 33 atau $66 \%$ responden. Para remaja ini beralasan bahwa bahasa Indonesia memang bahasa nasional tetapi menurut mereka tidak perlu dijaga juga akan tetap ada. Pada dasarnya para remaja ini masih memiliki keyakinan bahwa bahasa nasional kita adalah bahasa Indonesia akan tetapi rasa untuk menjaga dan memelihara ini yang perlu kita tingkatkan.

Poin di atas berbanding lurus dengan poin atau pernyataan yang kedua. Adapun pernyataan kedua adalah "Merasa memiliki bahasa Indonesia sehingga harus dilestarikan". Pada poin ini para remaja pada dasarnya masih merasa memiliki bahasa Indonesia tetapi untuk melestarikannya mereka merasa itu bukan tanggung jawab mereka. Menurut para remaja ini tanpa mereka menjaga bahasa Indonesia bahasa ini akan tetap ada dan dipakai oleh semua orang Indonesia. Pada poin ini sebanyak 40 atau $80 \%$ responden memilih poin negatif. Hal ini karena ada pernyataan "dilestarikan". Selebihnya, sebanyak 10 atau $20 \%$ responden memilih poin positif. Beberapa remaja yang memilih poin positif mengatakan bahwa kalau bukan remaja seperti mereka maka siapa lagi yang akan melestarikan bahasa Indonesia.

Pernyataan ketiga terkait dengan kesadaran akan adanya norma dan aturan dalam bahasa Indonesia berdasarkan teori Gavin dan Mathiot. Pernyataan ketiga berbunyi "Perlu mempelajari dan memperdalam bahasa Indonesia meskipun bahasa tersebut sudah dikuasai". Karena pada umumnya remaja yang menjadi responden adalah pelajar dan mahasiswa maka peneliti berasumsi bahwa mereka mendapatkan mata pelajaran atau mata kuliah Bahasa Indonesia. Dengan begitu, pernyataan ini sangat relevan dengan keadaan tersebut. Melihat pilihan jawaban yang disampaikan oleh responden maka dapat dikatakan bahwa para remaja ini memiliki kecenderungan sikap bahasa yang negatif. Sebanyak 47 atau 94\% responden memilih poin positif dan 3 atau $6 \%$ responden memilih poin negatif. Menurut para remaja yang menjadi responden hal tersebut lebih karena mereka mendapatkan mata pelajaran atau mata kuliah bahasa Indonesia di tempat mereka menimba ilmu.

Pernyataan ketiga ini juga terkait dengan pernyataan ketujuh yakni "Mempelajari bahasa Indonesia karena merasa membutuhkan". Apabila di pernyataan ketiga mengarah pada sikap positif maka berbalik atau berbeda dengan pernyataan ketujuh. Para responden menyampaikan bahwa mereka 
mempelajari Bahasa Indonesia lebih pada kewajiban sebagai sebuah mata pelajaran atau mata kuliah bukan karena kebutuhan. Pada pernyataan ketujuh hampir semua memilih poin yang mengarah pada sikap bahasa yang negatif. Para remaja merasa sudah mampu menggunakan bahasa Indonesia sehingga tidak merasa perlu lagi belajar. Akan tetapi, pernyataan ini justru dipatahkan sendiri oleh mereka melalui pernyataan kesepuluh.

Pernyataan kesepuluh adalah "Nilai bahasa Indonesia lebih baik daripada bahasa asing". Di pernyataan ketujuh mereka menyampaikan bahwa mereka belajar bahasa Indonesia hanya sebagai sebuah kewajiban mata pelajaran dan tidak perlu lagi mempalajarinya sebagai sebuah kebutuhan. Pada pernyataan kesepuluh justru sebagian besar responden mengatakan nilai Bahasa Indonesia mereka jauh lebih jelek dibandingkan dengan nilai bahasa asing. Hampir semua responden memperoleh nilai bahasa asing yang lebih tinggi dibandingkan dengan nilai bahasa Indonesia. Meskpun demikian, mereka justru merasa lebih bangga karena merasa lebih pandai dalam berbahasa asing.

Hal yang demikian didukung dengan poin yang dipilih pada pernyataan keempat, yakni "Orang tua lebih senang dan bangga melihat Anda menguasai bahasa Indonesia dibandingkan bahasa asing". Pada pernyataan tersebut sebanyak 36 atau $72 \%$ responden menyatakan kalau orang tua mereka lebih senang anaknya mampu menggunakan bahasa asing daripada bahasa Indonesia. Hal tersebut dibuktikan dengan kegiatan menambah jam untuk belajar bahasa asing di luar jam sekolah. Para responden ini hampir semuanya mengikuti kursus bahasa asing sehingga nilai bahasa asing mereka lebih tinggi.
Pilihan pada pernyataan kelima juga mengindikasikan bahwa kondisi saat ini para orang tua lebih menginginkan anak-anak mereka menguasai dan menggunakan bahasa asing. Para orang tua ini merasa lebih bangga jika anak-anak mereka mampu atau lancar dalam menggunakan bahasa asing. Meskipun ketika anak-anak mereka menggunakan bahasa asing para orang tua ini merasa tidak paham. Hal tersebut justru membuat mereka lebih bangga karena berarti mereka dianggap telah berada di kalangan menengah ke atas. Mereka beranggapan bahwa anakanaknya harus mampu menguasai dan menggunakan bahasa asing dengan baik sehingga menurut mereka kesempatan untuk maju dan berkembang akan lebih terbuka.

Dalam kegiataan bermedia sosial para remaja ini juga mengikuti tren yang ada. Menurut mereka tren yang sedang berlangsung adalah mencampuradukkan antara bahasa Indonesia dengan bahasa asing. Dengan gaya atau tren yang demikian, maka setiap unggahan mereka selalu menggunakan bahasa Indonesia yang dicampur dengan bahasa asing. Para remaja yang tinggal di wilayah Tangerang Selatan yang berdekatan dengan Jakarta Selatan juga dihinggapi "virus \#anakjaksel". Dalam setiap unggahan di media sosial akan ditemukan percampuran bahasa yang terkadang justru membuat para pembacanya bingung dan mengernyitkan dahi. Hal tersebut terlihat pada poin yang dipilih dalam pernyataan keenam, yakni "Lebih senang dan bangga menggunakan bahasa Indonesia di media sosial dan dalam percakapan sehari-hari dibandingkan menggunakan bahasa asing". Lebih banyak responden merasa lebih senang dan bangga menggunakan bahasa asing dibandingkan dengan bahasa Indonesia atau paling tidak selalu 
memasukkan unsur bahasa asing dalam setiap postingan.

Pada pernyataan kedelapan, responden menyatakan bahasa Indonesia dirasa sangat penting tetapi tidak terlalu menuntut untuk dipelajari lebih lanjut. Menurut mereka, bahasa Indonesia yang mereka kuasai atau pelajari selama ini sudah cukup menjadi bekal bagi mereka untuk bekerja. Sementara itu, mereka merasa penting menguasai bahasa asing guna membuka kesempatan bekerja secara lebih luas.

Pernyataan

kesembilan

mempunyai indikasi pada sikap bahasa yang positif. Hal tersebut karena lebih banyak responden memilih poin positif dibandingkan poin negatif. Para remaja ini menggunakan bahasa Indonesia dibandingkan bahasa asing dalam berkomunikasi sehari-hari. Hal tersebut karena dalam kegiatan keseharian tidak banyak yang mampu menggunakan bahasa asing sehingga mereka tidak perlu menggunakan bahasa asing dalam berkomunikasi. Demikian juga dengan kegiatan pergaulan di lingkungan keluarga yang lebih banyak tidak menggunakan bahasa asing. Selain bahasa Indonesia mereka juga menggunakan bahasa daerah asal masing-masing dalam berkomunikasi dengan orang tua dan lingkungan sekitar.

\section{PENUTUP}

Berdasarkan analisis maka didapatkan simpulan bahwa lebih banyak responden yang memilih poin negatif pada angket yang disajikan. Dengan pilihan tersebut dapat dikatakan bahwa para remaja ini memiliki sikap bahasa yang negatif. Sikap bahasa yang negatif ini lebih dipengaruhi oleh lingkungan sekitar juga. Salah satunya adalah faktor orang tua yang merasa bahwa mereka lebih bangga jika anakanak mereka lebih menguasai bahasa asing dibandingkan bahasa Indonesia. Selain itu, faktor perluasan kesempatan kerja juga menjadi menjadi bahan pertimbangan mereka dalam menyikapi bahasa asing dan bahasa Indonesia. Faktor lingkungan dan penggunaan media sosial secara aktif juga sangat berpengaruh. Bahasa-bahasa yang beredar dan digunakan di media sosial yang lebih banyak bahasa asingnya membuat mereka juga menggunakan bahasa asing dalam setiap unggahan. Dengan simpulan tersebut maka sosialisasi terhadap pentingnya penggunaan bahasa Indonesia perlu digalakkan. Selain itu, penanaman rasa atau sikap bahasa yang positif juga perlu dilakukan melalui berbagai sarana.

\section{DAFTAR PUSTAKA}

Ali, H. \& Lilik P. (2016). Indonesia 2020: The urban middle-class millenials. Alvara Research Center

Aslinda \& Leni S. (2010). Pengantar Sosiolinguistik. Bandung: Angkasa

Chaer, A. \& Leoni A. (1995). Sosiolinguistik: Perkenalan awal. Jakarta: Rineka Cipta

Hartono. (2009). Geografi 2 jelajah bumi dan alam semesta. Jakarta: Pusat Perbukuan Departemen Pendidikan Nasional

Jendra, I. M. I. (2010). Sociolinguistics (The study of societies language). Yogyakarta: Graha Ilmu

Mahsun. (2011). Metode penelitian bahasa: tahapan strategi, metode, dan tekniknya. Jakarta: PT. Raja Grafindo Persada

Nababan, P. W. J. (1993). Sosiolinguistik: Suatu pengantar. Jakarta: PT. Gramedia Pustaka Utama 
Rahardjo, M. (2007). Sosiologi pedesaan: Studi perubahan sosial. Malang: UIN Malang Press

Sumarsono. (2010). Sosiolinguistik. Yogyakarta: Sabda

Susilawati, S. A., et al. (2009). Geografi 2: Lingkungan fisik dan sosial. Jakarta: Pusat Perbukan Departemen Pendidikan Nasional Zalmansyah, A., Zakiah, K. N. \& Isnaini. (2018). Pengetahuan peraturan kebahasaan dalam memengaruhi sikap bahasa pedagang makanan di Kota Metro. Kandai, 14 (2), 149-168.

Syahrir. (2018). Generasi milenial???. Diperoleh dari http://rumahmillenials.com.

Pemerintah Kota Tangerang Selatan. (tt). Diperoleh dari https://www.tangerangselatankot a. go.id. 